Article

\title{
Enantioselective Chromatographic Separation and Lipase Catalyzed Asymmetric Resolution of Biologically Important Chiral Amines
}

\author{
Mohammed Farrag El-Behairy ${ }^{1, *(1)}$, Rasha M. Hassan ${ }^{2}$ and Eirik Sundby ${ }^{3}$ \\ 1 Department of Organic and Medicinal Chemistry, Faculty of Pharmacy, University of Sadat City, \\ Sadat City 32897, Egypt \\ 2 Medicinal and Pharmaceutical Chemistry Department, Pharmaceutical and Drug Industries Research \\ Division, National Research Centre (ID: 60014618), Dokki, Giza 12622, Egypt; rashahassan_pharma@yahoo.ca \\ 3 Department of Materials Science and Engineering, Norwegian University of Science and Technology (NTNU), \\ NO-7491 Trondheim, Norway; eirik.sundby@ntnu.no \\ * Correspondence: mohammed.farrag@fop.usc.edu.eg or mohabeha@gmail.com; Tel.: +20-1227163094
}

Citation: El-Behairy, M.F.; Hassan, R.M.; Sundby, E. Enantioselective Chromatographic Separation and Lipase Catalyzed Asymmetric Resolution of Biologically Important Chiral Amines. Separations 2021, 8, 165. https://doi.org/10.3390/ separations 8100165

Academic Editor: Igor Clarot

Received: 22 August 2021

Accepted: 11 September 2021

Published: 30 September 2021

Publisher's Note: MDPI stays neutral with regard to jurisdictional claims in published maps and institutional affiliations.

Copyright: (C) 2021 by the authors. Licensee MDPI, Basel, Switzerland. This article is an open access article distributed under the terms and conditions of the Creative Commons Attribution (CC BY) license (https:// creativecommons.org/licenses/by/ $4.0 /)$.

\begin{abstract}
Cyanoacetamides are vital synthons in synthetic organic chemistry. However, methods to enantiopure cyanoacetamides have not yet been well explored. In this work, the preparation of cyanoacetamide synthons $R S-(\mathbf{1 a}-\mathbf{4 a})$ or methoxyacetamides $R S-(\mathbf{1} \mathbf{b}-\mathbf{4 b})$ in enantiopure/enriched form was investigated. Compounds $S-\mathbf{1}, S-\mathbf{2}, R-\mathbf{1} \mathbf{b}, R-\mathbf{1} \mathbf{a}$, and $R-\mathbf{2} \mathbf{b}$ were prepared in enantiopure form (ee $>99 \%$ ) while compounds $S-4, R-2 a$, and $R$-4a were achieved in ee $9 \%, 80 \%$, and $76 \%$, respectively. Many baselines enantioselective HPLC separations of amines 1-4, their cyanoacetamides (1a-4a), and methoxyacetamides (1)-4b) were achieved by utilizing diverse mobile-phase compositions and two cellulose-based CSPs (ODH ${ }^{\circledR}$ and LUX- $3^{\circledR}$ columns). Such enantioselective HPLC separations were used to monitor the lipase-catalyzed kinetic resolution of amines $R S-(\mathbf{1}-\mathbf{4})$.
\end{abstract}

Keywords: cyanoacetamide; chiral amines; enantioselective chromatography; lipase; kinetic resolution

\section{Introduction}

Chiral aromatic amines and their amides are found in around $40 \%$ of all active pharmaceutical ingredients $[1,2]$ and are represented in many biologically important compounds, such as the natural products dysidenin, the antidiabetic repaglinide, the antidementia rivastigmine, the calcimimetic cinacalcet, and other drugs, as per Figure 1 [3]. Moreover, 1-arylpropan-2-amines symbolize a key pharmacophore in drugs used in the treatment of sleep disorders, depression, obesity, central and peripheral stimulant activity via affecting both serotonin (5-HT) receptor and monoamine oxidase (MAO) enzyme $[4,5]$. Of note, the biological activity of $\beta$-adrenergic receptor and histamine $\mathrm{H}_{3}$-receptor agonists that are derivatized from chiral aromatic amines are strongly related to the stereo-configuration of these chiral amines [6,7].

Based on their biological and synthetic impact, many asymmetric strategies have been adopted for the preparation of chiral amines in the enantiopure form [2,8]. Among such traditional methods are the crystallization of diastereoisomeric salt, enantioselective reduction of imines or enamines [9], C-H insertion hydro-functionalization of alkene [3,10,11], and nucleophilic addition [2,8,12]. Despite the wide applicability of chemical catalysis in asymmetric synthesis, biocatalysis has been introduced as a superior alternative to chemical catalysis and found plentiful applications in numerous fields particularly to make chiral building blocks for the pharmaceutical industry $[13,14]$. Of these building blocks, chiral amines were displayed as one of the most prominent examples where a plethora of biocatalysts have been implemented [1,15-17].

Cyanoacetamide is a key moiety in synthetic chemistry and it has a wide range of application prospects [18-22]. It represents a crucial intermediate of fine chemical industry 
such as medicine, agrochemicals, and dyes [21,23]. It is beneficial for the production of esters, amides, acids, and nitriles and is used as an intermediate for the synthesis of 3-cyanopiperidin-2,6-diones [24], substituted tetrahydroquinolines [25] 2-amino-4,6dimethoxypyrimidine an intermediate for sulfonylurea herbicides, and the insecticide flufenitrile [26].<smiles>CCCCC(C)N(C)C(=O)Oc1cccc([C@H](C)N(C)C)c1</smiles><smiles>CC(CCCc1cccc(C(F)(F)F)c1)NCCCNC(C)c1cccc2ccccc12</smiles>

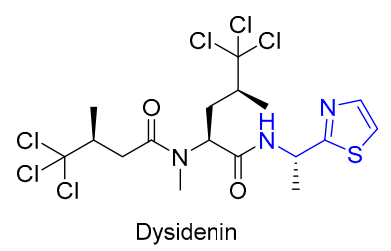<smiles>COc1ccccc1C1NCCCN1Cc1ccccc1</smiles>

CP 99,994<smiles>CN(C)C(CCOc1cccc2ccccc12)c1ccccc1</smiles><smiles>O=C(OC1CC=CC1)N1CCc2ccccc2C1c1ccccc1</smiles><smiles>CCOc1cc(CC(=O)NC(CC(C)C)c2ccccc2N2CCCCC2)ccc1C(=O)O</smiles><smiles>CNCc1ccc(C)c(C(=O)NC(C)c2cccc3ccccc23)c1</smiles>
SARS-COV PLpro inhibitor<smiles>O=C(O)COCCN1CCN(C(c2ccccc2)c2ccc(Cl)cc2)CC1</smiles>

Figure 1. Biologically important compounds containing chiral aromatic amines.

As a polyfunctional synthon with both electrophilic (C-3, C-1) and nucleophilic $(\mathrm{N}, \mathrm{C}-2)$ reactive sites (Figure 2) [21], cyanoacetamides have been customized to prepare diverse heterocyclic moieties $[21,22,27,28]$ with different ring sizes (Figure 2), such as azirine [29], pyrrole [30], thiophene [31,32], pyrazole [33], isothiazole [34], imidazole [35], thiazole [36], thiadiazole [37], pyridine [38], pyridinone [39], pyrane [40], pyridazine [41], pyrimidine [28], thiazine [42], and triazine [36].

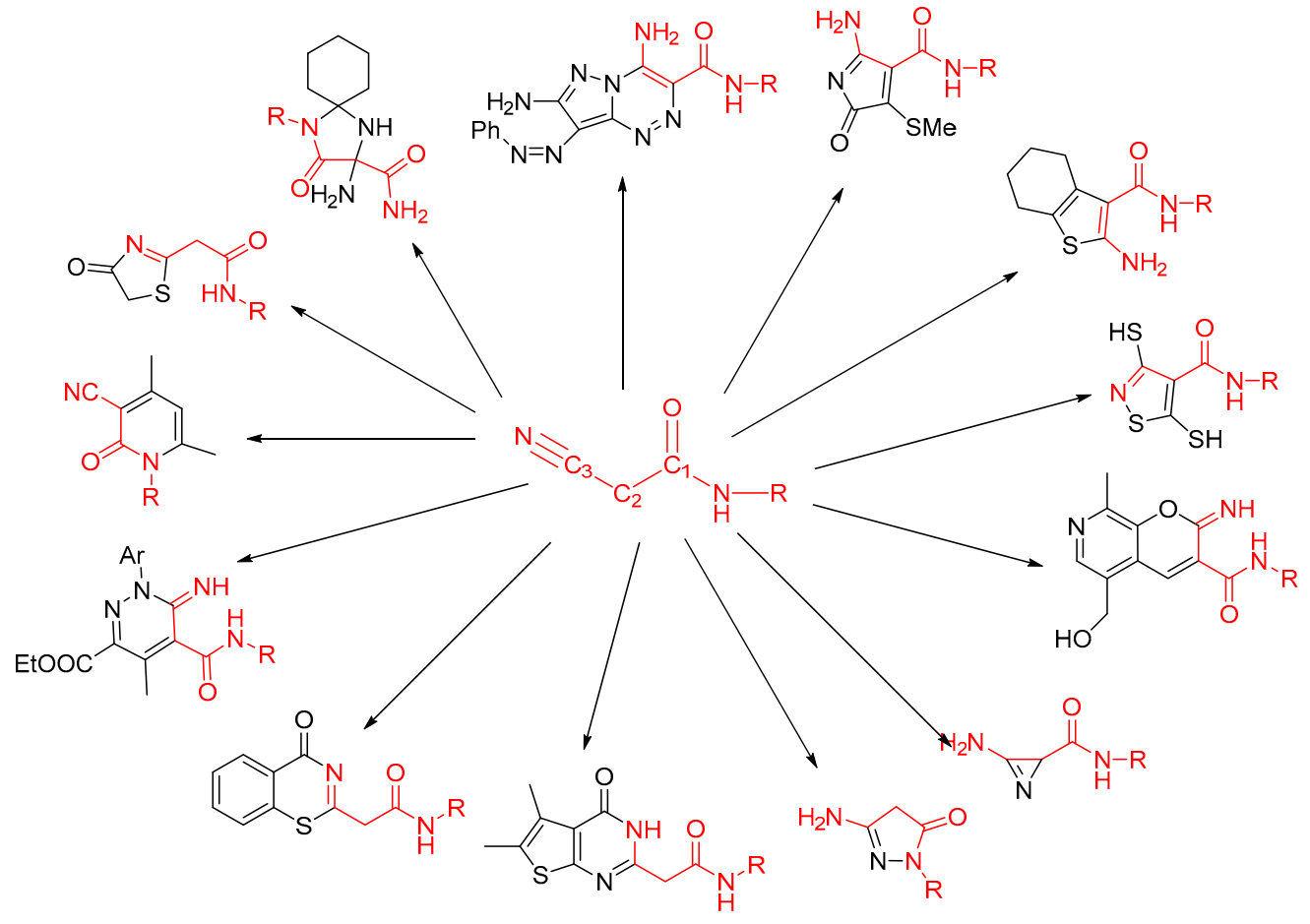

Figure 2. Diverse heterocyclic moieties synthesized from cyanoacetamide. 
In the present work, the lipase-catalyzed resolution of four chiral amines (1-4) was explored as a tool toward both kinetic resolution of amines (1-4) and bio-catalyzed asymmetric synthesis of their key synthons (cyanoacetamide (1a-4a) and methoxyacetamide $(\mathbf{1 b}-\mathbf{4 b})$. Finally, the enantioselective chromatographic separations of amines 1-4 and their cyanoacetamide (1a-4a) and methoxyacetamide $(\mathbf{1} \mathbf{b}-\mathbf{4} \mathbf{b})$ derivatives were investigated.

\section{Results and Discussion}

\subsection{Enantioselective Chromatographic Separation}

High-performance liquid chromatography (HPLC) equipped with chiral stationary phases (CSPs) is a well-established technique for chiral analysis [43,44]. It has replaced the old-fashion optical rotation method that does not allow for the tracing of distomer in eutomer [45]. The applicability of chiral liquid chromatography has been boosted following advances in chiral stationary phases [46]. Thus, straightforward enantioseparation using CSPs has been demonstrated as a ubiquitous approach for enantiomeric resolution.

Indeed, enantiomers' separation is very crucial for many quantitative and qualitative applications, such as quality control of chiral drugs; estimation of chiral drugs in biological samples; and following up pharmacological and toxicological studies, calculating enantiomeric excess in the asymmetric synthesis of chiral drugs and monitoring of diverse enantioselective reactions $[47,48]$. Hence, enantioseparation is targeting reliable and reproducible adequate baseline resolution of both enantiomers in a timely fashion with minimum cost.

In the present work, enantioselective HPLC equipped with polysaccharide CSP (namely LUX cellulose- $3{ }^{\circledR}$ and CHIRALCEL-ODH ${ }^{\circledR}$ Figure 3) was seized for the enantioseparation of chiral amines (1-4), their cyanoacetamides (1a-4a), and methoxyacetamides $(\mathbf{1 b}-\mathbf{4 b})$. Baseline enantioseparations of both reaction starts (amines 1-4) and reaction products (cyanoacetamides $(\mathbf{1 a}-\mathbf{4 a})$ or methoxyacetamides $(\mathbf{1} \mathbf{b}-\mathbf{4} \mathbf{b})$ are a prerequisite for all asymmetric reactions that catalyzed by either chemo or biocatalysts. These enantioseparations will be used to calculate the enantiomeric excess (ee) of the reaction components and monitor the reactions to precisely determine when to stop the reaction to get the best enantiomeric purity.<smiles>Cc1ccc(C(=O)OC2CC3CCC2C3)cc1</smiles>

Lux-3<smiles>Cc1cc(C)cc(NC(=O)OC(C)CCO)c1</smiles>

Figure 3. Chemical structures of LUX $3^{\circledR}$ and CHIRALCEL-ODH ${ }^{\circledR}$ CSPs.

Both LUX cellulose- $3{ }^{\circledR}$ and CHIRALCEL-ODH ${ }^{\circledR}$ are cellulose-based coated columns with tris(4-methylbenzoate) and tris(3,5-dimethylphenylcarbamate) as chiral selector, respectively (Figure 3). Both columns showed efficient separations under normal phase elution mode. Investigations had started using normal hexane, which was later replaced with cyclohexane for environmental factors [49]. The carbamate-based ODH column demonstrated superior efficiency toward the resolution of amines (1-4), while the esterbased Lux-3 column showed better selectivity for amides (1a-4a and $\mathbf{1} \mathbf{b}-\mathbf{4} \mathbf{b}$; Table 1 and Supplementary Materials Table S1, entries 13 and 14). Of note, diethylamine (DEA) as a basic additive was very impactful on the separation of both amines and amides. In absence of DEA, amines 1-4 were retained on the stationary phase and no peaks for the enantiomers were noticed even after $60 \mathrm{~min}$ run. This confirms the reports on basic additive role not only on enantioselective separation but also on elution [50,51]. 
Table 1. Chromatographic separation data for amines $\mathbf{1}-\mathbf{4}$, and amides $\mathbf{1 a}-\mathbf{4 a}$ and $\mathbf{1 b}-\mathbf{4} \mathbf{b}$.

\begin{tabular}{|c|c|c|c|c|c|c|c|}
\hline Entry & Cpd & Column & Mobile Phase & $\begin{array}{l}\text { Total Run } \\
\text { Time (Min) }\end{array}$ & $\begin{array}{l}\text { Mobile Phase } \\
\text { Composition }\end{array}$ & $\begin{array}{c}\text { Flow Rate } \\
\mathrm{mL} / \mathrm{min}\end{array}$ & Resolution(Rs) \\
\hline 1 & \multirow{6}{*}{1} & OD-H & $n$-hex/MtBE/ $i-\mathrm{PrOH} / \mathrm{DEA}$ & 14 & $95 / 5 / 0.5 / 0.1$ & 1.5 & 3.19 \\
\hline 2 & & OD-H & $n$-hex/MtBE/ $i-\mathrm{PrOH} / \mathrm{DEA}$ & 22 & $95 / 5 / 0.5 / 0.1$ & 1.0 & 3.63 \\
\hline 3 & & OD-H & $c$-hex/MtBE/ $i-\mathrm{PrOH} / \mathrm{DEA}$ & 10 & $93 / 5 / 2 / 0.1$ & 1.0 & 0.95 \\
\hline 4 & & OD-H & $c$-hex/MtBE/ $i-\mathrm{PrOH} / \mathrm{DEA}$ & 13 & $94 / 5 / 1 / 0.1$ & 1.0 & 1.18 \\
\hline 5 & & OD-H & $c$-hex/i-PrOH/DEA & 12 & $98 / 2 / 0.1$ & 1.0 & 1.25 \\
\hline 6 & & OD-H & $c$-hex/i-PrOH/DEA & 9 & $95 / 5 / 0.1$ & 1.0 & 1.11 \\
\hline 7 & \multirow{3}{*}{2} & OD-H & $n$-hex/MtBE/i-PrOH/DEA & 12 & $95 / 5 / 0.5 / 0.1$ & 1.5 & 1.21 \\
\hline 8 & & OD-H & $c$-hex/MtBE/ $i-\mathrm{PrOH} / \mathrm{DEA}$ & 10 & $93 / 5 / 2 / 0.1$ & 1.0 & 0.84 \\
\hline 9 & & OD-H & $c$-hex/MtBE/ $i-\mathrm{PrOH} / \mathrm{DEA}$ & 12 & $94 / 5 / 1 / 0.1$ & 1.0 & 1.0 \\
\hline 10 & 3 & I & I & / & I & / & / \\
\hline 11 & \multirow{9}{*}{4} & OD-H & $n$-hex/MtBE/i-PrOH/DEA & 12 & $95 / 5 / 0.5 / 0.1$ & 1.5 & 11.14 \\
\hline 12 & & OD-H & $n$-hex/EtOH/DEA & 6 & $95 / 5 / 0.1$ & 1.5 & 7.23 \\
\hline 13 & & Lux-3 & $c$-hex/EtOH/DEA & 5 & $9 / 1 / 0.1$ & 1.0 & 0.66 \\
\hline 14 & & OD-H & $c$-hex/EtOH/DEA & 6 & $9 / 1 / 0.1$ & 1.0 & 2.4 \\
\hline 15 & & OD-H & $n$-hex/EtOH/DEA & 8 & $9 / 1 / 0.1$ & 1.0 & 4.6 \\
\hline 16 & & OD-H & $c$-hex/MtBE/i-PrOH/DEA & 10 & $94 / 5 / 1 / 0.1$ & 1.0 & 11.6 \\
\hline 17 & & OD-H & $c$-hex/MtBE/ $i-\mathrm{PrOH} / \mathrm{DEA}$ & 9 & $93 / 5 / 2 / 0.1$ & 1.0 & 5.9 \\
\hline 18 & & OD-H & $c$-hex $/ i-\mathrm{PrOH} / \mathrm{DEA}$ & 10 & $98 / 2 / 0.1$ & 1.0 & 9.14 \\
\hline 19 & & OD-H & $c$-hex $/ i-\mathrm{PrOH} / \mathrm{DEA}$ & 8 & $95 / 5 / 0.1$ & 1.0 & 4.28 \\
\hline 20 & $1 \mathrm{a}$ & $\operatorname{Lux} 3$ & $n$-hex/EtOH/DEA & 12 & $9 / 1 / 0.2$ & 2.0 & 2.08 \\
\hline 21 & $2 a$ & $\operatorname{Lux} 3$ & $n$-hex/EtOH/DEA & 12 & $9 / 1 / 0.2$ & 2.0 & 3.03 \\
\hline 22 & $3 a$ & Lux 3 & $n$-hex/EtOH/DEA & 30 & $9 / 1 / 0.2$ & 2.0 & 1.58 \\
\hline 23 & $4 a$ & OD-H & $n$-hex/EtOH/DEA & 13 & $95 / 5 / 0.1$ & 1.5 & 1.59 \\
\hline 24 & $1 \mathrm{~b}$ & Lux 3 & $c$-hex/EtOH/DEA & 12 & $95 / 5 / 0.1$ & 1.0 & 1.04 \\
\hline 25 & $2 b$ & $\operatorname{Lux} 3$ & $c$-hex/EtOH/DEA & 13 & $95 / 5 / 0.1$ & 1.0 & 1.78 \\
\hline 26 & $3 b$ & OD-H & $n$-hex/EtOH/DEA & 16 & $95 / 5 / 0.2$ & 1.5 & 1.2 \\
\hline 27 & \multirow{2}{*}{$4 b$} & Lux 3 & $c$-hex/EtOH/DEA & 16 & $95 / 5 / 0.1$ & 1.5 & 16 \\
\hline 28 & & Lux 3 & $n$-hex/EtOH/DEA & 8 & $9 / 1 / 0.2$ & 2.0 & 2.13 \\
\hline
\end{tabular}

Abbreviations: $c$-hex (Cyclohexane)/ $n$-hex (normal hexane)/MtBE (methyl tertiary butyl ether)/ $i$-PrOH (isopropanol)/DEA (diethyl amine)/EtOH (ethanol).

Replacement of $n$-hexane with $c$-hexane afforded shorter runs, which is very beneficial for large sample numbers and prompt reaction monitoring; however, it reflected as lower resolutions (Table 1 and Supplementary Materials Table S1, entries 1-6, 14 and 15). Such an impact on the resolution was compensated via altering the alcohol modifier ratio and type. Subsequently, when the ethanol ratio lowered from $10 \%$ to $5 \%$ the resolution has increased from 4.6 to 7.23 (entries 12 and 15). In addition, decreasing the isopropanol ratio from $2 \%$ to $1 \%$ doubled the resolution (entries 16 and 17). On the other hand, replacing ethanol with isopropanol and/or $\mathrm{M} t \mathrm{BE}$ boosted the resolution tremendously (entries 11-19). Notably, MtBE revealed a remarkable impact on the resolution of amines, especially when used with $n$-hexane on ODH column counting it is incompatible with Lux-3 column. Despite trying a plethora of mobile phases (Table 1 and Supplementary Materials Table S1), amine $\mathbf{3}$ was inseparable whereas, amides (1a-4a and $\mathbf{1 b}-\mathbf{4 b}$ ) were separable only when ethanol was used as the modifier. Of note, enantioselective separation of cyanoacetamides (1a-4a) was achievable only when $n$-hexane was used as a mobile phase component while methoxyacetamides $(\mathbf{1} \mathbf{b}-\mathbf{4 b})$ were mainly resolved with $c$-hexane.

The superiority of carbamate column ODH in the resolution of amines but not amides and vice versa for Lux-3 is of interest in understanding the underlying mechanisms of chiral separation. This could be retrieved to steric factor that the amides (either cyanoor methoxy-acetamides) are bulkier than the amines and so the chiral selector of ODH ( $m$-dimethylphenyl) is bulkier than that of Lux-3 (4-methylphenyl) Figure 3. In addition, the electronic difference between the ester group of Lux-3 and the carbamate group of ODH is expected to be impactful on resolution considering the resolution of enantiomers is based 
on the interaction with the chiral selectors. Carbamate with dipolar nature can function as both $\mathrm{H}$-bond donor and acceptor, while the ester group is acting as an H-acceptor only [52].

\subsection{Lipase-Catalyzed Kinetic Resolution}

Biocatalysis has long been documented as a revolutionary technology in contemporary synthetic chemistry [53]. This fact has been supported by the recent advances in both enzyme engineering technologies that allow for the modification of the catalyst and global enzyme market which is anticipated to upsurge from \$7 billion to $\$ 10$ billion [54]. Biocatalysts offer outstanding activity and exceptional stereo-, regio-, and chemoselectivity [14]. Many biocatalysts have been reported to catalyzed stereoselective reactions, such as laccases [55,56], transaminases [56], and amidases [57]. Among these biocatalysts, lipase emerges as one of the most prevailing, with no cofactor needed, working in both aqueous and organic media, as well as catalyze hydrolysis, esterification, and amidation reactions $[47,48,58,59]$.

In this work, a set of four lipases (namely Cal-A, Cal-B, Candida rugose lipase, porcine pancreatic lipase) were screened for lipase-catalyzed amidation of amines 1-4 in MtBE as a solvent and using ethyl 2-cyanoacetate or ethyl 2-methoxyacetate as acyl donor. Cal-B was the sole active enzyme concerning both activity and selectivity. S-1 and S-2 were obtained via both lipase-catalyzed methoxyacetamide and cyanoacetamide, but the methoxyacetamide reaction was complete and afforded maximum yield ( $50 \%$ for kinetic resolution reactions) for both products ( $S$-amines $S-\mathbf{1}$ and $S-\mathbf{2}$ and $R$-methoxyacetamide $R-\mathbf{1 b}$ and $R-\mathbf{2} \mathbf{b}$ ) with a maximum enantiomeric excess (ee $>99 \%$, Table 2 ) for $S-\mathbf{1}, S-\mathbf{2}, R-\mathbf{1 b}$, and $R-\mathbf{2 b}$. Moreover, $S-\mathbf{1}$ and $S-\mathbf{2}$ were achievable via lipase-catalyzed cyanoacetamidation reaction but with lower yield and ee, since reactions were quenched early by filtering the enzyme (Table 2). The early stopping of lipase-catalyzed cyanoacetamidation reaction was due to the lower selectivity of the enzyme toward cyanoacetamide $R-\mathbf{1 a}$ and $R-\mathbf{2 a}$ and the second enantiomer S-1a and S-2a start to be traced by HPLC besides the fasterreacting enantiomers $R-\mathbf{1 a}$ and $R-\mathbf{2} \mathbf{a}$, which will result in very low enantiopurity. Thus, in these cases, the reaction should be ended early at the point when the fast-reacting enantiomer (in our case $R-\mathbf{1 a}$ and $R-\mathbf{2 a}$ ) is as enantiopure as possible. The excellent baseline HPLC separations (Table 1 and Supplementary Materials Table S1) of amines 1-4 and amides $\mathbf{1 a}-\mathbf{4} \mathbf{a}$ and $\mathbf{1 b}-\mathbf{4 b}$ (Figure 4) maintained such precise and accurate following up and supported an evidence-based-reaction ending decision.

Table 2. Data for lipase-catalyzed amidation reactions.

\begin{tabular}{cccc}
\hline Compound & Yield & (ee) & Reaction \\
\hline$S-\mathbf{1}$ & $49 \%$ & $>99 \%$ & methoxyacetamide \\
$S-\mathbf{2}$ & $49 \%$ & $>99 \%$ & methoxyacetamide \\
$\mathbf{3}$ & $/$ & $/$ & $/$ \\
$S-\mathbf{4}$ & $83 \%$ & $9 \%$ & cyanoacetamide \\
$R-\mathbf{1 a}$ & $10 \%$ & $>99 \%$ & cyanoacetamide \\
$R-\mathbf{2} \mathbf{a}$ & $25 \%$ & $80 \%$ & cyanoacetamide \\
$\mathbf{3} \mathbf{a}$ & $/$ & $/$ & $/$ \\
$R-\mathbf{4} \mathbf{a}$ & $16 \%$ & $76 \%$ & cyanoacetamide \\
$R-\mathbf{1 b}$ & $49 \%$ & $>99 \%$ & methoxyacetamide \\
$R-\mathbf{2} \mathbf{b}$ & $49 \%$ & $>99 \%$ & methoxyacetamide \\
$\mathbf{3 b}$ & $/$ & $/$ & $/$ \\
$\mathbf{4 b}$ & $/$ & $/$ & $/$ \\
\hline
\end{tabular}

* Enantiomeric excess.

Amine S-4 was also attainable but in low enantiopurity (ee 9\%) via lipase-catalyzed cyanoacetamidation, while $R-\mathbf{4}$ a was accomplished in enantioenriched form with a good enantiomeric excess (ee 76\%). For amine 3, despite the fact that the enantiomers of amides $\mathbf{3 a}$ and $\mathbf{3 b}$ were separated, the absence of baseline separation of the amine $\mathbf{3}$ prohibited following up the lipase-catalyzed reactions, since both the reaction start and product must be baseline separated. 
<smiles>CC(N)c1cccc(F)c1</smiles><smiles>CCOC(=O)CC[13CH3]</smiles><smiles>CCOC(=O)COC</smiles><smiles>CC(C)(C)C(N)c1ccccc1</smiles><smiles>CC(N)c1cccc(F)c1</smiles>

(S)-1<smiles>CC(NC(=O)CC#N)c1cccc(F)c1</smiles>

(R)-1a<smiles>COCC(=O)NC(C)c1cccc(F)c1</smiles>

(R)-1b<smiles>COCC(=O)NC(C)c1cc(F)cc(F)c1</smiles><smiles>C[C@H](N)Cc1cccnc1</smiles>

(S)-3

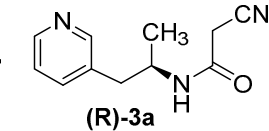<smiles>COCC(=O)NC(C)Cc1cccnc1</smiles>

(R)-3b<smiles>COCC(=O)NC(c1ccccc1)C(C)(C)C</smiles>

Figure 4. Schematic representation depicting the investigated amines 1-4 and the bio-catalyzed asymmetric synthesis of cyanoacetamide (1a-4a) and methoxyacetamide $(\mathbf{1} \mathbf{b}-\mathbf{4} \mathbf{b})$.

The enantiomeric excess of all compounds (Table 2) was calculated based on the enantioselective baseline separations using HPLC (Table 1; Supplementary Materials Tables S1 and S2; Figure 5; and Supplementary Materials Figures S1 and S2). The reaction progress of lipasecatalyzed methoxyamidation of amines $\mathbf{1}$ and $\mathbf{2}$ is represented in Figure 5, where chromatograms $\mathrm{A} 1$ and $\mathrm{B} 1$ showed a reaction status at zero time, where both enantiomers of amines are represented equally. After $17 \mathrm{~h}$, chromatograms A2 and B2 showed the $R$-amines are decreasing with $S$-amines still unreacted yet due to the $R$-stereoselectively of the CAL-B enzyme [17,60,61]. Chromatograms A3 and B3 are showing that the $R$-enantiomers are completely disappeared, and the reactions were stopped at this time to get $S$-amines $S-\mathbf{1}$ and $S-\mathbf{2}$ and $R$-methoxyacetamides $R-\mathbf{1} \mathbf{b}$ and $R-\mathbf{2 b}$ in enantiopure form (ee $>99 \%$ ). The absolute configurations were estimated based on that Cal-B enzyme is reported to act $R$-stereoselectively the case that reported for further enzymes too, such as laccases, transaminases, and amidases [17,57,60-63].
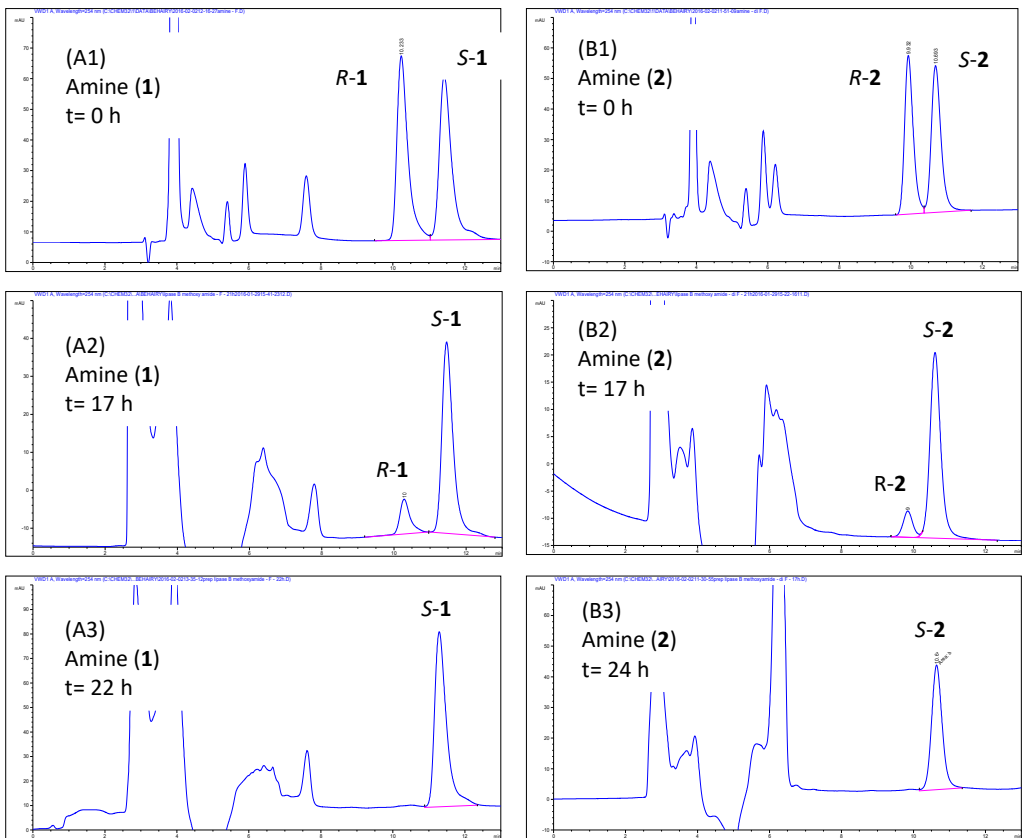

Figure 5. HPLC chromatograms of reaction progress of Cal-B enantioselective methoxyacetamidation of amines 1 and 2. 


\section{Materials and Methods}

3.1. General

All solvents used were analytical or Chromatographic grade and were purchased from Sigma-Aldrich (Steinheim, Germany). Immobilized Candida antarctica lipase B (Novozym 435, activity 10,000 PLU/g, lot no. LC 200205) was from Novozymes (Bagsværd, Denmark). Lipase A from Candida antarctica immobilized on Immobead 150 (activity 500 U/g, lot no. 1388471), Candida rugose lipase, and porcine pancreatic lipase were bought from Sigma (Netherlands). Ethyl 2-methoxyacetyate, ethylcyanacetates, and all other chemicals and solvents were purchased from Sigma-Aldrich. NMR spectra were carried out on a Bruker $400 \mathrm{MHz}$ Spectrophotometer, using TMS as an internal standard. Chemical-shift values are recorded in ppm $\delta$ scale. An AIKA KS 4000 shaker incubator was used for the enzyme reactions. Enantiomeric ratios, $E$, were calculated based on ping-pong bi-bi kinetics, using the computer program E $\mathcal{E}$ K Calculator (2.1b0 PCC) [64], based on the calculations of Chen and Rakes [65,66].

\subsection{Chromatographic System}

HPLC Agilent 1100 system (Agilent, Santa Clara, CA, USA) with a quaternary pump and a variable wavelength UV detector and equipped with Chiracel OD-H ${ }^{\circledR}(\mathrm{CHIRAL}$ TECHNOLOGIES EUROPE S.A.S, CEDEX, France) or Lux-3 cellulose columns (Phenomenex, CA, USA) i.d. $4.6 \mathrm{~mm}, 25 \mathrm{~cm}$, and $5 \mu \mathrm{m}$. Moreover, $c$-hex (Cyclohexane)/n-hex (normal hexane)/MtBE (methyl tertiary butyl ether)/ $i$-PrOH (isopropanol)/DEA (diethyl amine)/EtOH (ethanol) (Steinheim, Germany) were used as eluents; mobile phase compositions, flow rates, runs time, and resolutions are summarized in Table 1 . The temperature of analysis was room temperature, and the wavelength at which the detection was made is $254 \mathrm{~nm}$.

\subsection{Synthesis of Racemic $\mathbf{1} a / b-4 a / b$}

Racemic amides $\mathbf{1 a} / \mathbf{b}-\mathbf{4 a} / \mathbf{b}$ were prepared from the corresponding amines $\mathbf{1 - 4}$ (Figure 4 ) following the reported procedures [67]. Thus, ethyl 2-cyanoacetate or ethyl 2-methoxyacetate $(0.001 \mathrm{~mol})$ was added to a solution of 1-4 $(0.001 \mathrm{~mol})$ in toluene $(2 \mathrm{~mL})$ and stirred at room temperature for $72 \mathrm{~h}$. The solvent was removed under reduced pressure. The product was washed with cooled diethyl ether $(2-3 \mathrm{~mL})$.

\subsubsection{2-Cyano-N-(1-(3-fluorophenyl)ethyl)acetamide (1a)}

Yield (117 mg, 50\%), ${ }^{1} \mathrm{H}$ NMR (400 MHz, $\left.\mathrm{CDCl}_{3}\right) \delta 7.51-7.17$ (m, 2H), 7.17-6.82 (m, $3 \mathrm{H}), 4.98(\mathrm{~s}, 1 \mathrm{H}), 3.37(\mathrm{~s}, 2 \mathrm{H}), 1.44(\mathrm{~s}, 3 \mathrm{H})$.

\subsubsection{2-Cyano-N-(1-(3,5-difluorophenyl)ethyl)acetamide (2a)}

Yield (113 mg, 45\%), ${ }^{1} \mathrm{H}$ NMR (400 MHz, $\left.\mathrm{CDCl}_{3}\right) \delta 6.89-6.82(\mathrm{~m}, 2 \mathrm{H}), 6.74(\mathrm{~d}, J=8.8,2.2 \mathrm{~Hz}$, $1 \mathrm{H}), 6.59(\mathrm{~d}, J=5.9 \mathrm{~Hz}, 1 \mathrm{H}), 5.06(\mathrm{p}, J=7.1 \mathrm{~Hz}, 1 \mathrm{H}), 3.42(\mathrm{~s}, 2 \mathrm{H}), 1.53(\mathrm{~d}, J=10.9 \mathrm{~Hz}, 3 \mathrm{H})$.

\subsubsection{2-Cyano-N-(1-(pyridin-3-yl)propan-2-yl)acetamide (3a)}

Yield (100 mg, 38\%), ${ }^{1} \mathrm{H}$ NMR $\left(400 \mathrm{MHz}, \mathrm{CDCl}_{3}\right) \delta 8.39(\mathrm{dd}, J=4.8,1.6 \mathrm{~Hz}, 1 \mathrm{H}), 8.34$ $(\mathrm{d}, J=1.9 \mathrm{~Hz}, 1 \mathrm{H}), 7.55(\mathrm{~d}, J=7.8 \mathrm{~Hz}, 1 \mathrm{H}), 7.42(\mathrm{~s}, 1 \mathrm{H}), 7.24(\mathrm{dd}, J=7.8,4.9 \mathrm{~Hz}, 1 \mathrm{H}), 4.21$ $(\mathrm{dt}, J=13.6,6.8 \mathrm{~Hz}, 1 \mathrm{H}), 3.34(\mathrm{~s}, 2 \mathrm{H}), 2.85-2.69(\mathrm{~m}, 2 \mathrm{H}), 1.17(\mathrm{~d}, J=6.7 \mathrm{~Hz}, 3 \mathrm{H})$.

\subsubsection{2-Cyano-N-(2,2-dimethyl-1-phenylpropyl)acetamide (4a)}

Yield (127 mg, 55\%), ${ }^{1} \mathrm{H}$ NMR $\left(400 \mathrm{MHz}, \mathrm{CDCl}_{3}\right) \delta 7.33-7.23(\mathrm{~m}, 3 \mathrm{H}), 7.21(\mathrm{~d}, J=1.6 \mathrm{~Hz}$, 2H), $7.19(\mathrm{~s}, 1 \mathrm{H}), 3.48(\mathrm{~s}, 2 \mathrm{H}), 3.37(\mathrm{~d}, J=7.8 \mathrm{~Hz}, 2 \mathrm{H}), 0.91(\mathrm{~d}, J=8.1 \mathrm{~Hz}, 6 \mathrm{H})$.

3.3.5. N-(1-(3-Fluorophenyl)ethyl)-2-methoxyacetamide (1b)

Yield (95 mg, 40\%), ${ }^{1} \mathrm{H}$ NMR (400 MHz, $\left.\mathrm{CDCl}_{3}\right) \delta 7.25-6.75(\mathrm{~m}, 5 \mathrm{H}), 5.22-5.02(\mathrm{~m}, 1 \mathrm{H})$, 3.95-3.78 (s, 2H), $3.37(\mathrm{~s}, 3 \mathrm{H}), 1.46(\mathrm{~d}, J=6.8 \mathrm{~Hz}, 3 \mathrm{H})$. 


\subsubsection{N-(1-(3,5-Difluorophenyl)ethyl)-2-methoxyacetamide (2b)}

Yield (90 mg, 35\%), $\left.{ }_{1}^{1} \mathrm{H} \mathrm{NMR} \mathrm{(400} \mathrm{MHz,} \mathrm{CDCl}_{3}\right) \delta 6.80(\mathrm{~m}, 3 \mathrm{H}), 6.65(\mathrm{~m}, 1 \mathrm{H}), 5.09(\mathrm{~m}$, $1 \mathrm{H}), 3.98(\mathrm{~s}, 2 \mathrm{H}), 3.40(\mathrm{~d}, J=4.5 \mathrm{~Hz}, 3 \mathrm{H}), 1.45(\mathrm{~d}, J=7.0 \mathrm{~Hz}, 3 \mathrm{H})$.

\subsection{General Procedure for Lipase-Catalyzed Amidation}

Racemic amines $\left(7.2 \times 10^{-5} \mathrm{~mol}\right)((\mathrm{RS})-1,-2,-3,-4)(10 \mathrm{mg}, 11.3 \mathrm{mg}, 11.5 \mathrm{mg}, 10 \mathrm{mg})$ was dissolved in MtBE $(2 \mathrm{~mL})$ in a $5 \mathrm{~mL}$ glass vial followed by addition of acyl donor $(8.0 \mu \mathrm{L}$, $7.2 \times 10^{-5} \mathrm{~mol}, 1$ eq.) and Lipase ( $20 \mathrm{mg}$, Cal-A, Cal-B, Candida rugose lipase, porcine pancreatic lipase). The mixture was heated to $40{ }^{\circ} \mathrm{C}$, stirred at $300 \mathrm{rpm}$. A sample of $50 \mu \mathrm{L}$ was collected, diluted with ethanol to $300 \mu \mathrm{L}$, and then $20 \mu \mathrm{L}$ was injected on the HPLC system equipped with the appropriate chiral column, as per Table 1.

\section{Conclusions}

Lipase-catalyzed cyanoamidation and methoxyamidation of amines RS-(1-4) aiming at the preparation of enantiopure amines 1-4 and cyanoacetamides 1a-4a were performed. The asymmetric reactions were monitored by chiral HPLC that were developed using cellulose-based CSPs (ODH and LUX-3). Enantioselective separations were utilized to estimate the enantiomeric purity of afforded compounds in terms of enantiomeric excess. Compounds $S-\mathbf{1}, S-\mathbf{2}, R-\mathbf{1} \mathbf{b}, R-\mathbf{1} \mathbf{a}$, and $R-\mathbf{2} \mathbf{b}$ were prepared in enantiopure form (ee $>99 \%$ ), while compounds $S-4, R-2 a$, and $R-4 a$ were achieved in ee $9 \%, 80 \%$, and $76 \%$ respectively. The developed baseline chiral HPLC analyses are reliable and reproducible and of interest to follow up pharmacological and toxicological studies, calculate enantiomeric excess in asymmetric synthesis, and monitor diverse enantioselective reactions.

Supplementary Materials: The following are available online at https:/ /www.mdpi.com/article/10 .3390/separations8100165/s1. Table S1: HPLC chromatograms of baseline separations of amines 1-4, amides $\mathbf{1 a}-\mathbf{4 a}$ and $\mathbf{1 b}-\mathbf{4} \mathbf{b}$ as per condition in Table 1. Table S2: Chromatograms of lipase-catalyzed reactions used to calculate enantiomeric excess. Figure S1: HPLC chromatograms showing baseline separation of racemic amine $R S-\mathbf{1}(\mathrm{C})$, methoxyacetamide $R S-\mathbf{1 b}(\mathrm{A})$, the enantiopure $S-\mathbf{1}(\mathrm{D})$, and $R-\mathbf{1 b}$ (B) afforded from the kinetic resolution by lipase ensuring enantiomeric purity. Figure S2: HPLC chromatograms showing baseline separation of racemic amine RS-2 (B), methoxyacetamide $R S-2 \mathbf{b}$ (A), the enantiopure $S-2$ (D), and $R-\mathbf{2 b}$ (B) afforded from the kinetic resolution by lipase ensuring enantiomeric purity. Figure S3: ${ }^{1} \mathrm{H}-\mathrm{NMR}$ of compound 1a. Figure S4: ${ }^{1} \mathrm{H}-\mathrm{NMR}$ of compound 2a. Figure S5: ${ }^{1} \mathrm{H}-\mathrm{NMR}$ of compound 3a. Figure S6: ${ }^{1} \mathrm{H}-\mathrm{NMR}$ of compound 4a. Figure S7: ${ }^{1} \mathrm{H}-\mathrm{NMR}$ of compound $\mathbf{1 b}$. Figure S8: ${ }^{1} \mathrm{H}-\mathrm{NMR}$ of compound $\mathbf{2 b}$.

Author Contributions: Conceptualization, M.F.E.-B. and E.S.; methodology, M.F.E.-B., R.M.H. and E.S.; writing—original draft preparation, M.F.E.-B.; writing—review and editing, M.F.E.-B., R.M.H. and E.S. All authors have read and agreed to the published version of the manuscript.

Funding: This research was funded by project number 90399700 (PI. Eirik Sundby).

Institutional Review Board Statement: Not applicable.

Informed Consent Statement: Not applicable.

Data Availability Statement: Not available.

Conflicts of Interest: The authors declare no conflict of interest.

\section{References}

1. Lakó, Á.; Molnár, Z.; Mendonça, R.; Poppe, L. Transaminase-mediated synthesis of enantiopure drug-like 1-( $\left(3^{\prime}, 4^{\prime}\right.$-disubstituted phenyl) propan-2-amines. RSC Adv. 2020, 10, 40894-40903. [CrossRef]

2. Ghislieri, D.; Turner, N.J. Biocatalytic Approaches to the Synthesis of Enantiomerically Pure Chiral Amines. Top. Catal. 2014, 57, 284-300. [CrossRef]

3. He, Y.; Song, H.; Chen, J.; Zhu, S. NiH-catalyzed asymmetric hydroarylation of N-acyl enamines to chiral benzylamines. Nat. Commun. 2021, 12, 638. [CrossRef] [PubMed]

4. Glennon, R.A. Central serotonin receptors as targets for drug research. J. Med. Chem. 1987, 30, 1-12. [CrossRef] 
5. Vilches-Herrera, M.; Miranda-Sepúlveda, J.; Rebolledo-Fuentes, M.; Fierro, A.; Lühr, S.; Iturriaga-Vasquez, P.; Cassels, B.K.; Reyes-Parada, M. Naphthylisopropylamine and N-benzylamphetamine derivatives as monoamine oxidase inhibitors. Bioorg. Med. Chem. 2009, 17, 2452-2460. [CrossRef] [PubMed]

6. Morini, G.; Grandi, D.; Bertaccini, G.; Leschke, C.; Schunack, W. Stereoselective Inhibition of Ethanol- Induced Gastric Lesions in the Rat by the H3-Receptor Agonist (R)- $\alpha$-Methylhistamine and Its (S)-Configured Isomer. Pharmacology 1999, 59, 192-200. [CrossRef]

7. Harada, H.; Hirokawa, Y.; Suzuki, K.; Hiyama, Y.; Oue, M.; Kawashima, H.; Yoshida, N.; Furutani, Y.; Kato, S. Novel and potent human and rat $\beta 3$-Adrenergic receptor agonists containing substituted 3-indolylalkylamines. Bioorg. Med. Chem. Lett. 2003, 13, 1301-1305. [CrossRef]

8. Royer, J. Chiral Amine Synthesis. Methods, Developments and Applications. Angew. Chem. Int. Ed. 2010, 49, 7841. [CrossRef]

9. Dasgupta, S.; Morzhina, E.; Schäfer, C.; Mhadgut, S.C.; Prakash, G.K.S.; Török, B. Synthesis of Chiral Trifluoromethyl Benzylamines by Heterogeneous Catalytic Reductive Amination. Top. Catal. 2016, 59, 1207-1213. [CrossRef]

10. Zhu, S.; Niljianskul, N.; Buchwald, S.L. Enantio-and regioselective CuH-catalyzed hydroamination of alkenes. J. Am. Chem. Soc. 2013, 135, 15746-15749. [CrossRef]

11. Miki, Y.; Hirano, K.; Satoh, T.; Miura, M. Copper-Catalyzed Intermolecular Regioselective Hydroamination of Styrenes with Polymethylhydrosiloxane and Hydroxylamines. Angew. Chem. Int. Ed. 2013, 52, 10830-10834. [CrossRef]

12. Yuanwei, C.; Aiqiao, M.; Xun, X.; Yaozhong, J. Asymmetric Synthesis VIII: Enantioselective Synthesis of (R) or (S)- $\alpha$-Substituted Benzylamines VIA Chiral Pinanone Ketimine Template. Synth. Commun. 1989, 19, 1423-1430. [CrossRef]

13. Wu, S.; Snajdrova, R.; Moore, J.C.; Baldenius, K.; Bornscheuer, U.T. Biocatalysis: Enzymatic Synthesis for Industrial Applications. Angew. Chem. Int. Ed. 2021, 60, 88-119. [CrossRef] [PubMed]

14. Winkler, C.K.; Schrittwieser, J.H.; Kroutil, W. Power of Biocatalysis for Organic Synthesis. ACS Cent. Sci. 2021, 7, 55-71. [CrossRef] [PubMed]

15. Gill, I.I.; Das, J.; Patel, R.N. Enantioselective enzymatic acylation of 1-(3'-bromophenyl) ethylamine. Tetrahedron Asymmetry 2007, 18, 1330-1337. [CrossRef]

16. Csuka, P.; Boros, Z.; Örfi, L.; Dobos, J.; Poppe, L.; Hornyánszky, G. Chemoenzymatic route to Tyrphostins involving lipasecatalyzed kinetic resolution of 1-phenylethanamine with alkyl cyanoacetates as novel acylating agents. Tetrahedron Asymmetry 2015, 26, 644-649. [CrossRef]

17. Sánchez, V.M.; Rebolledo-Vicente, F.; Gotor, V. CandidaantarcticaLipase-Catalyzed Doubly Enantioselective Aminolysis Reactions. Chemoenzymatic Synthesis of 3-Hydroxypyrrolidines and 4-(Silyloxy)-2-oxopyrrolidines with Two Stereogenic Centers. J. Org. Chem. 1999, 64, 1464-1470. [CrossRef]

18. Chen, H.; Bao-wei, Z.; Liang, H.; He, Y.; Hao-yi, W. Study on optimum synthesis of ethyl cyanoacetate. E3S Web Conf. 2020, 213, 01010. [CrossRef]

19. DeRosa, T.F. Nitro Derivatives. In Advances in Synthetic Organic Chemistry and Methods Reported in US Patents; Elsevier: Oxford, UK, 2006; pp. 410-419. [CrossRef]

20. Ziarani, G.M.; Moradi, R.; Lashgari, N.; Kruger, H.G. Introduction and Importance of Synthetic Organic Dyes. In Metal-Free Synthetic Organic Dyes; Elsevier: Oxford, UK, 2018; pp. 1-7.

21. Fadda, A.A.; Bondock, S.; Rabie, R.; Etman, H.A. Cyanoacetamide derivatives as synthons in heterocyclic synthesis. Turk. J. Chem. 2008, 32, 259-286.

22. Ammar, Y.A.; Ali, M.M.; Mohamed, Y.A.; Thabet, H.K.; El-Gaby, M. Cyanoacetanilide intermediates in heterocyclic synthesis. Part 7: Preparation of some spiro[indoline-3,4'-pyridine] and chromeno[3,4-c] pyridine derivatives. Heterocycl. Commun. 2013, 19, 195-200. [CrossRef]

23. Hermanson, D.; Tompkins, J.G.; Veliyath, R.; Ye, Z. The compensation committee process. Contemp. Account. Res. 2012, 29, 666-709. [CrossRef]

24. Paprocki, D.; Berłożecki, S.; Ostaszewski, R. Environmental-friendly one-pot cascade synthesis of 3-cyanopiperidin-2,6-diones. Environ. Chem. Lett. 2020, 18, 165-170. [CrossRef]

25. Palanimuthu, A.; Chen, C.; Lee, G.-H. Synthesis of highly substituted tetrahydroquinolines using ethyl cyanoacetate via aza-Michael-Michael addition. RSC Adv. 2020, 10, 13591-13600.

26. Dupont, P.; Védrine, J.C.; Paumard, E.; Hecquet, G.; Lefebvre, F. Heteropolyacids supported on activated carbon as catalysts for the esterification of acrylic acid by butanol. Appl. Catal. A Gen. 1995, 129, 217-227. [CrossRef]

27. Gouda, M.A.; Sabah, M.A.; Aljuhani, W.K.; El-Gahani, A.S.; El-Enazi, S.A.E.-K.; Al Enizi, S.A.; Al-Balawi, M.M. Utility of 2-cyano-N-(2-hydroxyethyl) acetamide in heterocyclic synthesis. Eur. J. Chem. 2015, 6, $219-224$.

28. Fadda, A.A.; Rabie, R. Cyanoacetylation of amines: Recent advances in preparation methods and their synthetic uses in the formation of biologically active compounds. Res. Chem. Intermed. 2016, 42, 771-811. [CrossRef]

29. Eremeev, A.V.; Piskunova, I.P. Synthesis of 2-amino-1-azirines and their reactions with carboxylic acids. Chem. Heterocycl. Compd. 1985, 21, 998-1002. [CrossRef]

30. Elgemeie, G.H.; Elghandour, A.H.; Elzanate, A.M.; Ahmed, S.A. Synthesis of some novel $\alpha$-cyanoketene S, S-acetals and their use in heterocyclic synthesis. J. Chem. Soc. Perkin Trans. 1 1997, 3285-3290. [CrossRef]

31. Massoud, M. Cyanoacetamide derivatives as synthons in heterocyclic synthesis. Mansoura J. Pharm. Sci 1999, 15, 94. 
32. Elgemeie, G.H.; Mohamed, M.A. $\alpha$-Cyanodithioic Acids and Their Corresponding Mono-and Dithiolate Salts as Building Blocks for the Synthesis of Novel Mercaptothiophenes. Synth. Commun. 2006, 36, 1025-1038. [CrossRef]

33. Kurz, T.; Widyan, K.; Elgemeie, G.H. Novel Synthesis of Fluorinated Cyanoketene N, S-Acetals and Their Conversions to Fluorinated Pyrazole Derivatives. Phosphorus Sulfur Silicon Relat. Elem. 2006, 181, 299-304. [CrossRef]

34. Elgemeie, G.H.; Elzanaty, A.M.; Elghandour, A.H.; Ahmed, S.A. Novel Alkylsulfanylisothiazoles and Alkylsulfanylthiophenes Using Sodium $\alpha$-Cyanoketene Dithiolates as Starting Materials. Synth. Commun. 2006, 36, 825-834. [CrossRef]

35. Elgemeie, G.H.; Elghandour, A.H.; Elaziz, G.W.A. Novel Synthesis of Heterocyclic Ketene N, N-, N, O-, and N, S-Acetals Using Cyanoketene Dithioacetals. Synth. Commun. 2003, 33, 1659-1664. [CrossRef]

36. Farag, A.M.; Dawood, K.M.; Elmenoufy, H.A. A convenient route to pyridones, pyrazolo [2, 3-a] pyrimidines and pyrazolo [5, 1-c] triazines incorporating antipyrine moiety. Heteroat. Chem. Int. J. Main Group Elem. 2004, 15, 508-514. [CrossRef]

37. Dankova, E.F.; Bakulev, V.A.; Grishakov, A.N.; Mokrushin, V.S. Rearrangement of 5-amino-1, 2, 3-thiadiazole-4-carbothioamides. Bull. Acad. Sci. USSR Div. Chem. Sci. 1988, 37, 987-989. [CrossRef]

38. Gorecki, D.K.J.; Hawes, E.M. 2,3-Disubstituted 1,8-naphthyridines as potential diuretic agents. J. Med. Chem. 1977, $20,124-128$.

39. Metwally, N.H.; Abdelrazek, F.M. Heterocyclic Synthesis with Nitriles: Synthesis of some novel pyrrolo [2,1-b] thiadiazoline, pyrrolo[2,1-b]thiadiazolo[3,2-a]pyrimidine and pyridine derivatives. J. Für Prakt. Chem. 1998, 340, 676-678. [CrossRef]

40. Zhuravel, I.O.; Kovalenko, S.M.; Ivachtchenko, A.V.; Balakin, K.V.; Kazmirchuk, V.V. Synthesis and antimicrobial activity of 5-hydroxymethyl-8-methyl-2-(N-arylimino)-pyrano [2, 3-c] pyridine-3-(N-aryl)-carboxamides. Bioorg. Med. Chem. Lett. 2005, 15, 5483-5487. [CrossRef]

41. El Rady, E.A.; Barsy, M.A. A convenient and facile synthesis of pyridine, pyridazine, pyrimido-[4,5-c] pyridazine, pyrido[3,4c]pyridazine, 1,6-naphthyridine and phthalazine derivatives. J. Heterocycl. Chem. 2006, 43, 243-248. [CrossRef]

42. Liepa, A.J.; Saubern, S. 2-Substituted 5, 6-dihydro-1, 3-thiazines from nitriles and thiocyanates: A modification of Meyers's method. Aust. J. Chem. 1997, 50, 755-758. [CrossRef]

43. Chankvetadze, B. Recent trends in preparation, investigation and application of polysaccharide-based chiral stationary phases for separation of enantiomers in high-performance liquid chromatography. TrAC Trends Anal. Chem. 2020, 122, 115709. [CrossRef]

44. Okamoto, Y.; Ikai, T. Chiral HPLC for efficient resolution of enantiomers. Chem. Soc. Rev. 2008, 37, 2593-2608. [CrossRef] [PubMed]

45. Vojtylová-Jurkovičová, T.; Vaňkátová, P.; Urbańska, M.; Hamplová, V.; Sýkora, D.; Bubnov, A. Effective control of optical purity by chiral HPLC separation for ester-based liquid crystalline materials forming anticlinic smectic phases. Liq. Cryst. 2021, 48, 43-53. [CrossRef]

46. El-Behairy, M.F.; El-Azzouny, A.A. Enantioselective HPLC separation of bioactive C5-chiral 2-pyrazolines on lux amylose-2 and lux cellulose-2: Comparative and mechanistic approaches. J. Liq. Chromatogr. Relat. Technol. 2016, 39, 346-353. [CrossRef]

47. El-Behairy, M.F.; Sundby, E. One-step lipase-catalysed preparation of eslicarbazepine. RSC Adv. 2016, 6, 98730-98736. [CrossRef]

48. El-Behairy, M.F.; Sundby, E. Synthesis of the antiepileptic (R)-Stiripentol by a combination of lipase catalyzed resolution and alkene metathesis. Tetrahedron Asymmetry 2013, 24, 285-289. [CrossRef]

49. Yara-Varon, E.; Fabiano-Tixier, A.S.; Balcells, M.; Canela-Garayoa, R.; Bily, A.; Chemat, F. Is it possible to substitute hexane with green solvents for extraction of carotenoids? A theoretical versus experimental solubility study. RSC Adv. 2016, 6, 27750-27759. [CrossRef]

50. Gogaladze, K.; Chankvetadze, L.; Tsintsadze, M.; Farkas, T.; Chankvetadze, B. Effect of basic and acidic additives on the separation of some basic drug enantiomers on polysaccharide-based chiral columns with acetonitrile as mobile phase. Chirality 2015, 27, 228-234. [CrossRef] [PubMed]

51. Mosiashvili, L.; Chankvetadze, L.; Farkas, T.; Chankvetadze, B. On the effect of basic and acidic additives on the separation of the enantiomers of some basic drugs with polysaccharide-based chiral selectors and polar organic mobile phases. J. Chromatogr. A 2013, 1317, 167-174. [CrossRef]

52. DeRuiter, J. Amides and related functional groups. Princ. Drug Action 2005, 1, 1-16.

53. Sheldon, R.A.; Woodley, J.M. Role of Biocatalysis in Sustainable Chemistry. Chem. Rev. 2018, 118, 801-838. [CrossRef]

54. Abdelraheem, E.M.M.; Busch, H.; Hanefeld, U.; Tonin, F. Biocatalysis explained: From pharmaceutical to bulk chemical production. React. Chem. Eng. 2019, 4, 1878-1894. [CrossRef]

55. Bassanini, I.; Ferrandi, E.; Riva, S.; Monti, D. Biocatalysis with Laccases: An Updated Overview. Catalysts 2020, 11, 26. [CrossRef]

56. Albarrán-Velo, J.; Lavandera, I.; Gotor-Fernández, V. Sequential Two-Step Stereoselective Amination of Allylic Alcohols through the Combination of Laccases and Amine Transaminases. ChemBioChem 2020, 21, 200-211. [CrossRef] [PubMed]

57. Komeda, H.; Harada, H.; Washika, S.; Sakamoto, T.; Ueda, M.; Asano, Y. A novel R-stereoselective amidase from Pseudomonas sp. MCI3434 acting on piperazine-2-tert-butylcarboxamide. JBIC J. Biol. Inorg. Chem. 2004, 271, 1580-1590. [CrossRef] [PubMed]

58. Jacobsen, E.E.; Anthonsen, T.; El-Behairy, M.F.M.A.; Sundby, E.; Aboul-Enein, M.N.; Attia, M.I.; El-Azzouny, A.A.E.-S.; Amin, K.M.; Abdel-Rehim, M. Lipase Catalysed Kinetic Resolution of Stiripentol. Int. J. Chem. 2012, 4, 7.

59. Sun, M.; Nie, K.; Wang, F.; Deng, L. Optimization of the Lipase-Catalyzed Selective Amidation of Phenylglycinol. Front. Bioeng. Biotechnol. 2020, 7, 486. [CrossRef]

60. Kazlauskas, R.J.; Weissfloch, A.N.; Rappaport, A.T.; Cuccia, L.A. A rule to predict which enantiomer of a secondary alcohol reacts faster in reactions catalyzed by cholesterol esterase, lipase from Pseudomonas cepacia, and lipase from Candida rugosa. J. Org. Chem. 1991, 56, 2656-2665. [CrossRef] 
61. Jacobsen, E.E.; Anthonsen, T. Enantiopure derivatives of 1,2-alkanediols: Substrate requirements of lipase B fromCandida antarctica. Chirality 2000, 12, 654-659. [CrossRef]

62. Martínez-Montero, L.; Gotor, V.; Gotor-Fernández, V.; Lavandera, I. Stereoselective amination of racemic sec-alcohols through sequential application of laccases and transaminases. Green Chem. 2017, 19, 474-480. [CrossRef]

63. Song, Y.-L.; Zhang, Q.-W.; Li, Y.-P.; Yan, R.; Wang, Y.-T. Enantioseparation and Absolute Configuration Determination of AngularType Pyranocoumarins from Peucedani Radix Using Enzymatic Hydrolysis and Chiral HPLC-MS/MS Analysis. Molecules 2012, 17, 4236-4251. [CrossRef] [PubMed]

64. Anthonsen, H.W.; Hoff, B.; Anthonsen, T. Calculation of enantiomer ratio and equilibrium constants in biocatalytic ping-pong bi-bi resolutions. Tetrahedron Asymmetry 1996, 7, 2633-2638. [CrossRef]

65. Rakels, J.L.L.; Romein, B.; Straathof, A.J.J.; Heijnen, J.J. Kinetic analysis of enzymatic chiral resolution by progress curve evaluation. Biotechnol. Bioeng. 1994, 43, 411-422. [CrossRef]

66. Chen, C.S.; Fujimoto, Y.; Girdaukas, G.; Sih, C.J. Quantitative analyses of biochemical kinetic resolutions of enantiomers. J. Am. Chem. Soc. 1982, 104, 7294-7299. [CrossRef]

67. Kumar, M.; Madhukar, B.S.; Sridhar, M.A.; Bhadregowda, D.G.; Kapoor, K.; Gupta, V.K.; Kant, R. (R)-2-Cyano-N-(1-phenylethyl) acetamide. Acta Crystallogr. Sect. E Struct. Rep. Online 2013, 69, o653. [CrossRef] [PubMed] 